\title{
Retrospective Assesment of Spleen Injuries in Children: Ten Years of Experience in A Single Centre
}

\section{Çocuklarda Dalak Yaralanmalarının Geriye Dönük Değerlendirilmesi: Tek Bir Merkezde On Yıllık Deneyim}

\author{
Mehmet Uysal \\ Karamanoğlu Mehmetbey University, Faculty of Medicine, Karaman Training and Research Hospital, Department of Pediatric Surgery, \\ Karaman, Turkey
}

\begin{abstract}
Objective: We aimed to assess the causes of trauma that result in spleen and accompanying organ injuries, management types, and results of management in children referred to our clinic for spleen injuries in the last ten years.
\end{abstract}

Material and Method: The reports of 76 (56 boys, 20 girls) patients managed for spleen injuries owing to blunt abdominal trauma between June 2011 and May 2021 were reviewed retrospectively.

Results: The patients were aged between 2-17 (8.7 \pm 5.4$)$ years old; $56(73.7 \%)$ were boys and 20 (26.3\%) were girls. Causes of injuries included accidents involving a motorized vehicle $(37,48.7 \%)$, falls from height $(21,27.6 \%)$, sports/bumping into obstacles $(14,18.3 \%)$, a crash object in the abdomen (3,3,9\%), kick from a horse 1 (1.3\%). Isolated spleen injury was present in 42 patients (55.3\%), while 34 patients (44.7\%) had other organ injuries. Spleen injuries were grade I in 9 patients (11.8\%), grade II in 18 (23.7.\%), grade III in 27 $(35.6 \%)$, grade IV in $19(25 \%)$, and grade V in $3(3.9 \%)$. Splenectomy was performed in three patients (3.9\%) owing to hemodynamic instability and small intestine repair owing to a small intestine injury in two patients $(2.6 \%)$. None of these patients died from splenic injuries, but one of our patients died from brain injury while in nonoperative treatment.

Conclusion: Conservative treatment methods should be chosen in patients with a spleen injury who are hemodynamically stable. The shorter duration of hospital stay, less blood transfusion requirement, and lower morbidity, mortality percentages are indispensable reasons for this method to be preferred. The probability of other organ injuries should be thought of besides splenic trauma.
Öz

Amaç: Son on yılda dalak yaralanmaları nedeniyle kliniğimize başvuran çocuklarda dalak ve beraberindeki organ yaralanmalarına neden olan travma nedenlerini, tedavi tiplerini ve tedavi sonuçlarını değerlendirmeyi amaçladık.

Gereç ve Yöntem: Haziran 2011-Mayıs 2021 tarihleri arasında künt karın travmasına bağlı dalak yaralanması nedeniyle tedavi edilen 76 (56 erkek, 20 kız) hastanın raporları retrospektif olarak incelendi.

Bulgular: Hastaların yaşları 2-17 (8,7 $\pm 5,4)$ arasında; 56'sı $(\% 73,7)$ erkek, 20'si $(\% 26,3)$ kız idi. Yaralanmaların nedenleri arasında motorlu taşıtla ilgili kazalar $(\% 37,48,7)$, yüksekten düşme $(\% 21,27,6)$, spor/engellere çarpma $(\% 14,18,3)$, karın duvarına bir nesnenin çarpması $(\% 3,3,9)$, atın tekme atması $1(\% 1,3)$ yer aldı. 42 hastada $(\% 55,3)$ izole dalak yaralanması mevcutken, 34 hastada $(\% 44,7)$ başka organ yaralanmaları vardı. Dalak yaralanmaları 9' unda grade I (\%11,8), 18' inde grade II $(\% 23,7), 272$ 'sinde grade III $(\% 35,6), 19^{\prime}$ unda grade IV (\%25) ve $3^{\prime}$ ünde gradeV $(\% 3,9)$ idi. Hemodinamik instabilite nedeniyle üç hastada $(\% 3,9)$ splenektomi ve iki hastada $(2,6 \%)$ incebarsak yaralanması nedeniyle incebarsak onarımı yapıldı. Bu hastaların hiçbiri dalak yaralanmasından ölmedi, ancak hastalarımızdan biri ameliyatsız tedavi sırasında beyin hasarından öldü.

Sonuç: Dalak yaralanması olan ve hemodinamik olarak stabil olan hastalarda konservatif tedavi yöntemleri seçilmelidir. Hastanede kalıs süresinin kısalması, kan transfüzyonu gereksiniminin azalması ve morbidite, mortalite yüzdelerinin düşmesi bu yöntemin tercih edilmesinin vazgeçilmez nedenleridir. Dalak travmasının yanısıra diğer organ yaralanmalarının olasılığı düşünülmedir.

Anahtar Kelimeler: Travma, çocuklar, dalak, tedavi

Corresponding (iletişim): Mehmet Uysal, Department of Pediatric Surgery, Karamanoğlu Mehmetbey University School of Medicine, Karaman Training and Research Hospital, Karaman, Turkey

E-mail (E-posta): drmyzuysal3@gmail.com

Received (Geliș Tarihi): 12.09.2021Ａccepted (Kabul Tarihi): 09.12 .2021 


\section{INTRODUCTION}

The trauma is inducing death and disability in children. More than $90 \%$ of the pediatric age group entries worldwide are the outcome of a blunt mechanism, with $10 \%$ of these including the abdomen and pelvis. The spleen is the most widely affected intra-abdominal organ in children due to blunt abdominal traumas. Liver and kidney traumas are frequently contused organs with the spleen. ${ }^{[1,2]}$ The abdominal organs in children are at an unreasonable risk of organ injuries owing to a higher transmission rate of forces through the slight abdominal wall, bigger relative surfaces of the solid abdominal organs; for example spleen and liver, more elastic ribs, and more horizontal positioning of the diaphragm in children contrasted to adults. ${ }^{[3]}$

Blunt abdominal traumas are most widely seen in traffic accidents, falls from height, and bicycle accidents. The treatment alternatives for splenic injuries are conservative treatment, splenoraphy, ligation of the splenic artery, partial or total splenectomy. Splenectomy or splenoraphy were the most considerable methods especially in the quarter of the last century.

However, the spleen includes a critical role in immune function, and because of the risk of sepsis due to grampositive bacteria in asplenic patients, conservative treatment is currently more popular. ${ }^{[4]}$

The right and exact diagnosis for splenic injury decline morbidity and mortality. Abdominal x-ray graphy, ultrasonography (US), and computed tomography (CT) are the most widely used monitoring methods for diagnosis and follow-up in case of splenic trauma. Surgical methods are used less in solid organ injuries because of developments in radiology. ${ }^{[5]}$

We aimed to assess the causes of trauma that result in spleen and accompanying organ injuries, management types, and results of management in children referred to our clinic for spleen injuries in the last ten years

\section{MATERIAL AND METHOD}

This study was conducted by ethics committee approval obtained from Karamanoğlu Mehmetbey University Faculty of
Medicine (06-12/10.09.2021). All procedures were carried out in accordance with the ethical rules and the principles of the Declaration of Helsinki. The records of 76 patients managed for splenic injuries owing to blunt abdominal trauma between June 2011 and May 2021 were examined.

In addition to demographic features of the patients such as age and gender, duration of stay in the hospital, causes of trauma, additional organ injuries, and treatment methods were examined. Hemodynamic status was determined with blood pressure at referral, hemoglobin levels, and essential for blood transfusion. All splenic trauma patients were accepted to the intensive care unit and their vital parameters (heart rate, number of breaths, blood pressure, urine output, and density) were assessed hourly and hemoglobin levels were measured at the 6th and 24th hours. Injuries were diagnosed by history, physical examination, US, and/or contrast CT. US and CT examinations were performed by a radiologist. Splenic injuries were graded according to the classification of the American Association for the Surgery of Trauma (AAST).

The need for blood transfusion and treatment modalities were examined. Patients with hemodynamic stability were managed conservatively. Patients with evidence of perforation of the bowels or low hemoglobin levels in spite of blood transfusions underwent surgery. Patients were classified according to a retrospective analysis of their records. Hemodynamic stability was determined by blood pressure hemoglobin levels and by performing blood transfusions.

\section{RESULTS}

The patients were aged between 2-17 (8.7 \pm 5.4$)$ years; 56 (73.7\%) were boys, $20(26.3 \%)$ were girls involved in this study. Patients were categorized according to treatment methods, into the non-operative treatment (NOT) (group I) or operative treatment (OT) (group II). Their blood pressures, hemoglobin levels, blood transfusion, stay in intensive care and hospitalization times were examined (Table 2).

Causes of injuries included accidents involving a motorized vehicle $(37,48.7 \%)$, falls from height $(21,27.6 \%)$, sports/ bumping into obstacles $(14,18.3 \%)$, a crash object in the abdomen (3.3, 9\%), kick from a horse 1 (1.3\%).

\begin{tabular}{|c|c|c|c|c|}
\hline Grade & Injury type & Description of injury & ${ }^{*} \mathbf{n}$ & **\% \\
\hline \multirow[t]{2}{*}{ I } & Hematoma & Subcapsular $<10 \%$ surface area & 9 & 11.8 \\
\hline & Laceration & Capsular tear, $<1 \mathrm{~cm}$ parenchymal depth & & \\
\hline \multirow[t]{2}{*}{ II } & Hematoma & Subcapsular, $10 \%$ to $50 \%$ surface area Intraparenchymal, $<5 \mathrm{~cm}$ in diameter & 18 & 23.7 \\
\hline & Laceration & Capsular tear, $1 \mathrm{~cm}$ to $3 \mathrm{~cm}$ parenchymal depth that doesn't involve a trabecular vessel & & \\
\hline \multirow[t]{2}{*}{ III } & Hematoma & $\begin{array}{l}\text { Subcapsular, }>50 \% \text { surface area or expanding: ruptured subcapsular or parenchymal hematoma: intraparenchymal } \\
\text { hematoma_>5 cm or expanding. }\end{array}$ & 27 & 35.6 \\
\hline & Laceration & $3 \mathrm{~cm}$ parenchymal depth or involving trabecular vessels & & \\
\hline IV & Laceration & Laceration involving segmental or hilar vessels producing major devascularization ( $>25 \%$ of the spleen) & 19 & 25 \\
\hline \multirow[t]{2}{*}{ V } & Laceration & Completely shattered spleen & 3 & 3.9 \\
\hline & Vascular & Hilar vascular injury with devascularizes spleen & & \\
\hline
\end{tabular}


Systolic and diastolic blood pressures were lower in group II than in group I. Hb levels were considerably lower in group II than in group I. All of the patients in group II needed blood transfusions, whereas only $45.2 \%$ of patients treated in group I needed transfusions. Length of stay in intensive care and hospitalization time was significantly longer in group II than in group I (Table 2). X-ray graphy, US, and CT were used as diagnostic methods. CT was used for grading and other organ injuries in patients in whom splenic lacerations were detected in the US. Intra-abdominal free fluid was seen in the US in $65(71.1 \%)$ patients. The splenic laceration was diagnosed directly in US in the $64(71.1 \%)$ patients. In CT assessments splenic injuries were classed as grade I in 9 (11.8\%) patients, grade II in 18 (23.7.1\%), grade III in 27 (35.6\%), grade IV in 19 (25\%), and grade $\mathrm{V} 3$ (3.9\%) patients.

\begin{tabular}{|c|c|c|}
\hline & Group I (n. 70) & Group II (n. 6) \\
\hline Systolic blood pressure & $105 \mathrm{mmHg}(95-120)^{*}$ & $95 \mathrm{mmHg}(70-110)^{*}$ \\
\hline Diastolic blood pressure & $70 \mathrm{mmHg}(55-80)^{*}$ & $65 \mathrm{mmHg}(50-75)^{*}$ \\
\hline Average $\mathrm{Hb}$ value & $10.4 \mathrm{gr} / \mathrm{dL}(10-12)^{*}$ & $8.2 \mathrm{gr} / \mathrm{dL}(7-10.5)^{*}$ \\
\hline $\begin{array}{l}\text { Transfusion (number of } \\
\text { patients) }\end{array}$ & $38(\% 45)$ & $6(\% 100)$ \\
\hline $\begin{array}{l}\text { Stay in intensive care unit } \\
\text { (day) }\end{array}$ & $2(1-3)^{*}$ & $3(2-4)^{*}$ \\
\hline Lenght of stay (LOS) (day) & $4(3-6)^{*}$ & $7.5(5-9)^{*}$ \\
\hline
\end{tabular}

Patients with grade I and II injuries were treated conservatively whereas patients who had grade III (one patient), grade IV (one patient), grade $\mathrm{V}$ (one patient) injuries were treated surgically (Table 2). Two patients with subdiaphragmatic air were disclosed small bowel injury in X-ray.

Splenic injury alone was observed in 42 (55.3\%) patients and in conjunction with other organ injuries in 34 (44.7\%) patients. Other organ injuries included brain injuries in 11 (14.5\%) patients, the liver in 9 (11.8\%), lung in 7 (9.2\%), kidney in 5 (6.6\%), and bowel in 2 (2.6\%) patients.

Seventy-one patients (93.4\%) were treated conservatively, whereas $5(6.6 \%)$ required surgery. Splenectomy was performed in three patients. Also, small bowel repair was done in two $(2.6 \%)$ patients who had intestinal perforation. One of our patients died from brain injury while NOT.

\section{DISCUSSION}

The present first reason for death in children is trauma. Even in highly developed countries, traffic accidents account for the majority of deaths ${ }^{[6]}$ which is verified by this study. After the year 2000, there was a remarkable change towards NOT of splenic injury, with a total success rate of $97 \%$. NOT is thought the gold standart for the treatment of patients with blunt splenic trauma (BST) who are hemodynamically stable after a conservative approach, in the absence of peritonitis and associated injuries needing laparotomy. ${ }^{[7]}$

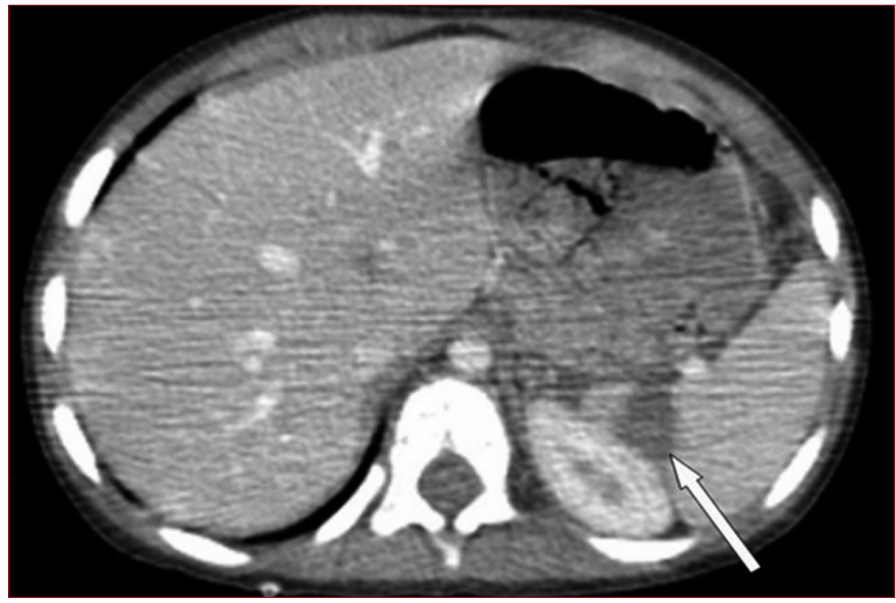

Figure 1. Axial enhanced CT image showing grade 2 splenic lacerations

A study disclosed that 36 (52\%) of 69 patients had trauma due to domestic violence, $11(16 \%)$ patients had trauma due to falls from height, 8 (11.5\%) from traffic accidents, and 14 (20\%) patients from fights, sporting activities and other reasons. Fights and sports accidents are the most common causes of solid organ injuries in adults while falls from height, traffic and bicycle accidents and falling objects are the most frequent causes of injury in children. ${ }^{[8]}$ Our study included patients who had traumas because of accidents involving a motorized vehicle $(37,48.7 \%)$, falls from height $(21,27.6 \%)$, sports/bumping into obstacles (14, 18.3\%), a crash object in the abdomen $(3.3,9 \%)$, kick from a horse 1 (1.3\%).

Multi-trauma organ injuries occur after abdominal traumas in children because the dimensions of children are big, the surface area of children is limited and the intraabdominal organs are closer to each other. The liver is the most commonly injured organ with the spleen. ${ }^{[9,10]}$ Liver injuries came after brain injuries in our study. This finding is different from those in the literature.

NOT including frequent physical examination, monitoring, bed rest, and hemoglobin measurements is the preferred mode of treatment in children because splenic traumas in children are well defined. Infection risk after splenectomy is higher in children than in adults, so conservation of the spleen is very important. A considerable number of grade 1-4 and $40 \%$ of grade 5 lacerations pull through well with NOT. In general, studies have shown that progress with NOT has a success level of $90-98 \%$ in children. ${ }^{[11]}$ While all grade 1 and 2 lacerations were treated NOT in this study, one patient who underwent splenectomy had grade 3 laceration and one had grade 4 laceration, one had grade 5 laceration. The number of patients treated with NOT was 71 (93.4\%). This result is well-matched with the literature. We can there infer that the need for surgery in cases of high-grade injury is lower in children than in adults.

We take notice that accompanying abdominal trauma can be an indication for surgery, and therefore lead to some form of spleen preserving treatment. In this study, there were 
two patients who underwent laparotomy for indications other than splenic injuries. In both patients, the spleen was protected.

Even on the initial CT scan, contrast extravasation can be succeeded at NOT when using an identified treatment protocol. The APSA protocol declares that treatment should be rested on physiological answers rather than radiologic properties of the injury. Fluid supplementation alone is often enough to balance up a pediatric patient hemodynamically (as opposed to adults). These proposals further prove that NOT is safe in the pediatric population, even in the presence of seemingly considerable injuries. Literature shows that the success rate for NOT in high-grade splenic injuries (IV and V) is very high if patient is hemodynamically stable.

The only difference with lower grade injuries is that the LOS increases considerably. ${ }^{[12,13]}$ In the NOT group LOS means 4, and the other OT group 7.5 days. This result is well-matched with the literature.

Abdominal CT findings such as intra-abdominal free fluid and enhancement of this fluid and contrast medium are used for adults in need of surgery; however, this is not true for children. ${ }^{[11]}$ US and CT are the most used diagnostic imaging methods recently. ${ }^{[12]}$ Insufficient recovery of vital signs in spite of adequate fluid replacement, another pathology requiring laparotomy, and the need for blood over the level of $40 \mathrm{ml} / \mathrm{kg} /$ day in pediatric patients are important criteria in determining surgical indications. ${ }^{[13]}$

Grading at CT was not indispensable parameter in deciding when surgery was necessary for this study; however, one patient with worsened hemodynamic and whose hemoglobin level did not rise in spite of blood transfusion underwent surgery. ${ }^{[14]}$ Forty-three of 46 patients $(93.5 \%)$ who had grade 3- 4 laceration on CT were managed NOT.

In this study Arikan et al. ${ }^{[4]}$ reported incidences of abscess in two patients, dermopancreatic fistula in one patient and aspiration pneumonia in one patient. There are increased risks of infection and sepsis who had a splenectomy, so NOT is indispensable for children particularly.

Kuzma et al. ${ }^{[8]}$ reported mean systolic blood pressure in a NOT group as $98 \mathrm{mmHg}$ and in a surgically treated group as 84 $\mathrm{mmHg}$. We detected the same parameter at the level of 105 $\mathrm{mmHg}$ in group I and $95 \mathrm{mmHg}$ in group II; mean diastolic blood pressures were $70 \mathrm{mmHg}$ in group I and $65 \mathrm{mmHg}$ in group II. Hypotension is an indispensable parameter when considering surgery. There was signified hypotension in group II in our study.

In Thompson et al. study the level of hemoglobin in the nonoperative group was $12.1 \mathrm{~g} / \mathrm{dl}$ and in the operative group was $11 \mathrm{~g} / \mathrm{dll}^{[4]}$ This parameter was $10.4 \mathrm{~g} / \mathrm{dl}$ in group I and $8.2 \mathrm{~g} / \mathrm{dl}$ in group II in our study. Blood transfusions were performed in four patients (12\%) in the nonoperative group and in five patients (83\%) in the operative group in Thompson et al. study. Jerzy et al. $^{[8]}$ indicated that patients in the NOT group needed 0.81 unit of blood and the OT group they needed 2.91 units of blood $(p<0.001)$. In this study the rate of blood transfusion in group I was $45 \%$ and in group II it was $100 \%$. If hemodynamic stability cannot be obtained in spite of enough blood transfusions, so OT must be performed. Blood transfusions must be conducted and hemodynamic stability must be determined in patients with splenic traumas before deciding on surgery.

\section{CONCLUSION}

This research article gives insight to us that most splenic traumas can be treated conservatively in pediatric patients who are hemodynamically stable. There are some advantages to conservative management like short hospitalization time, less blood transfusion requirement, and a lower morbidity and mortality rate in splenic injuries. Patients must be examined strictly before deciding on surgery. Falls from height and traffic accidents are important causes of splenic injuries. The probability of other organ injuries should be thought of besides splenic trauma. Because mortality might be occurred due to the concomitant injuries.

\section{ETHICAL DECLARATIONS}

Ethics Committee Approval: This study was conducted by ethics committee approval obtained from Karamanoğlu Mehmetbey University Faculty of Medicine (06-12/10.09.2021).

Informed Consent: Because the study was designed retrospectively, no written informed consent form was obtained from patients.

Referee Evaluation Process: Externally peer-reviewed.

Conflict of Interest Statement: The authors have no conflicts of interest to declare.

Financial Disclosure: The authors declared that this study has received no financial support.

Author Contributions: All of the authors declare that they have all participated in the design, execution, and analysis of the paper, and that they have approved the final version.

\section{REFERENCES}

1. Clemente N, Di Saverio S, et al. Management and outcome of 308 cases of liver trauma in Bologna Trauma Center in 10 years, Ann Ital Chir, 2011;82:351-60.

2. Dodgion CM, Gosain A, Rogers A, St Peter SD, Nichol PF, Ostlie DJ. National trends in pediatric blunt spleen and liver injury management and potential benefits of an abbreviated bed rest protocol. J Pediatr Surg. 2014;49(6):1004-8.

3. Klimek PM, Lutz T, Stranzinger E, Zachariou Z, Kessler U, Berger S Handlebar injuries in children. Pediatr Surg Int. 2013;29(3):269-73.

4. Arslan S, Guzel M, Turan C, Doğanay S, Kopru M. Management and treatment of splenic trauma in children. Ann Ital Chir,2015;86:30-34.

5. Visrutaratna P, Na-Chiangmai W. Computed tomography of blunt abdominal trauma in children. Singapore Med J 2008;49 (4):352.

6. McVay MR, Kokoska ER, Jackson RJ, et al. Throwing out the "grade" book:management of isolated spleen and liver injury based on hemodynamic status. J Pediatr Surg 2008;43:1072-6.

7. Juyia RF, Kerr HA. Return to play after liver and spleen trauma. Sports Health 2014;6:239-45. 
8. Kuzma J, Atua V:Conservative management of splenic injury in the tropics. Tropical doctor, 2008;38:210-21.

9. Wegner $\mathrm{S}$, Colletti JE, Van Wie D. Pediatric blunt abdominal trauma. Pediatry Clin North Am, 2006;53:243-56.

10. Sekmenli T, Gündüz M, Çiftçi I. Travmatik Dalak Yaralanması ve Akut Apandisit Birlikteliği:Olgu Sunumu, Zeynep Kamil Tıp Bülteni 2013;44:4850.

11. Ardley R, Carone L, Smith S, Spreadborough S, Davies P, Brooks A. Blunt splenic injury in children:the hemodynamic status key to guiding management, a 5-year review of practice in a UK major trauma centre. Eur J Trauma Emerg Surg. 2019;45(5):791-9

12. Leschied JR, Mazza MB, Davenport MS, et al. Inter-radiologist agreement for CT scoring of pediatric splenic injuries and effect on an established clinical practice guideline. Pediatr Radiol 2016; 46(2):229-36.

13. Yang K, Li Y, Wang C, Xiang B, Chen S, Ji Y. Clinical features and outcomes of blunt splenic injury in children:a retrospective study in a single institution in China. Medicine 2017;96(51):e9419.

14. Davies DA, Pearl RH, Ein SH. Management of blunt splenic injury in children:Evolution of the nonoperative approach. Journal of Pediatric Surgery, 2009;44:1005-8. 